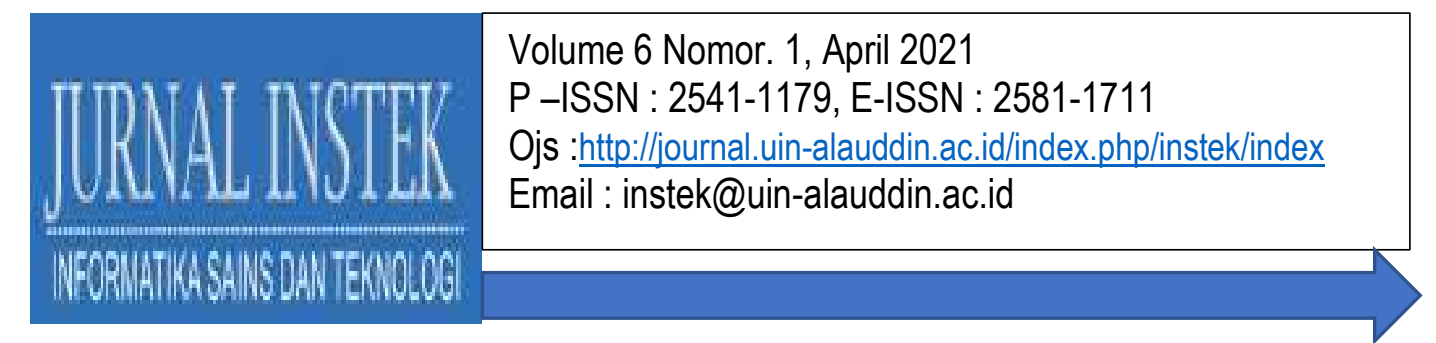

\title{
SISTEM INFORMASI AKADEMIK DAN MAHASISWA (SIMA) DI LINGKUNGAN KAMPUS UPI CIBIRU
}

\author{
HENDRIYANA ${ }^{1}$, INDIRA SYAWANODYA ${ }^{2}$ \\ Program Studi Rekaysa Perangkat Lunak ${ }^{1,2}$, Universitas Pendidikan Indonesia \\ J1. Dr. Setiabudhi No. 299, Bandung, Jawa Barat, Indonesia, 40154 \\ Email: hendriyana@upi.edu'1,indira@upi.edu ${ }^{2}$
}

\begin{abstract}
Abstrak
Perguruan Tinggi (PT) dalam meningkatkan pelayanan kepada sivitas akademika ialah dengan menerapkan dan menyediakan fasilitas pelayanan berbasis teknologi informasi dan komunikasi (TIK). Salah satu jenis pelayanan pada departement akademik dan kemahasiswaan ialah pelayanan administrasi permohonan observasi dan penelitian dilakukan menggunakan spereadsheet serta ditulis pada buku agenda. Universitas Pendidikan Indonesia Kampus Cibiru memiliki jumlah mahasiswa yang bertambah tiap tahunnya. Hal ini menimbulkan permintaan pelayanan bertambah sehingga menjadi kurang efisien karena memerlukan waktu proses permintaan yang relatif lama. Oleh karena itu, diperlukan prototipe sistem informasi yang merupakan tahapan pada metode waterfall untuk menganalisa kebutuhan pengguna. Prototipe diperlukan sebelum perangkat lunak sistem informasi dibangun dengan tujuan pembuatan perangkat lunak terstruktur dan tepat waktu. Implementasi metode yang digunakan menggunakan metode tersebut dilakukan pengujian dan validasi terhadap sistem yang telah berjalan menggunakan instrument aplikasi, analisa data, proses permohonan, penyimpanan data serta dokumentasi memberikan hasil SIMA efektif dan efisien dalam memantu tugas pokok dan fungsi akmawa.
\end{abstract}

Kata Kunci: Akademik, Perancangan Sistem Informasi, Sistem Informasi, Waterfall.

\section{PENDAHULUAN}

Kebutuhan informasi yang cepat dan tepat sangat diperlukan oleh perguruan tinggi, hal ini sangat berpengaruh kepada penyajian pelayanan yang dapat menyebabkan kebijakan langkah-langkah yang akan diambil. Informasi terkait yang berhubungan dengan aktifitas perkuliahan mahasiswa merupakan tugas pokok dan fungsi dari akademik dan kemahasiswaan (AKMAWA). Salah satu tugas pokok dan fungsi Akmawa antara lain penjadwalan perkuliahan, penjadwalan ruang kelas, 


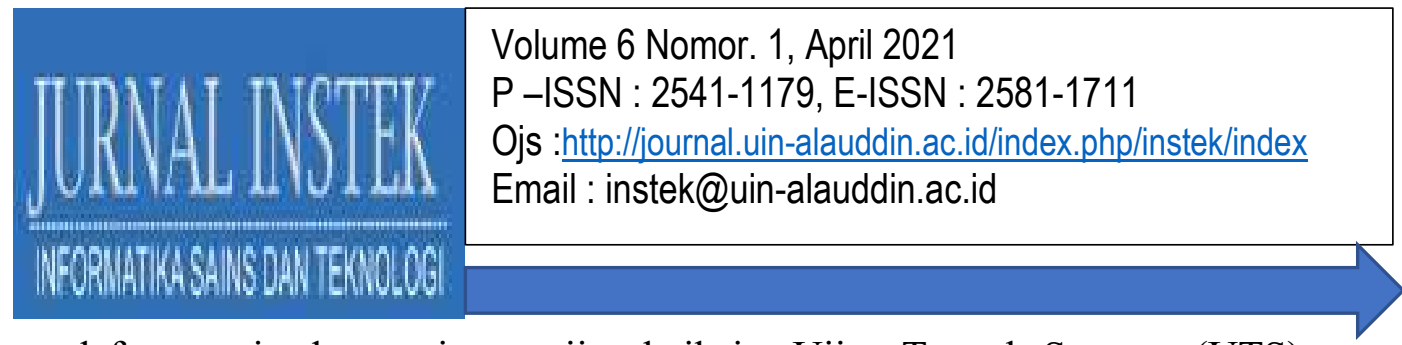

pendaftaran wisuda, persiapan ujian baik itu Ujian Tengah Semster (UTS) atau Ujian Akhir Semster (UAS), permohonan surat izin observasi dan penelitian mahasiswa, serta tugas pokok dan fungsi lainnya. Akmawa yang mengelola kegiatan aktifitas mahsiswa akan sangat membutuhkan pengolahan informasi dengan cepat dan tepat.

Berdasarkan data Sistem Informasi Akademik (SIAK) UPI tahun 2019 tercatat bahwa jumlah seluruh mahasiswa aktif ialah sebanyak 1.527 mahasiswa. Berkembangannya Ilmu Pengetahuan dan Teknologi (IPTEK) juga mendorong perguruan tinggi untuk mengikuti arah perkembangan pada arah tersebut. Untuk mendukung hal tersebut perlu perbaikan untuk bertransformasi dari konvensional menjadi digital. Tantangan saat ini yang sedang perlukan oleh Akmawa ialah tugas pokok dan fungsi untuk melayani permintaan mahasiswa terkait surat izin untuk melakukan observasi dan penelitian yang masih digunakan secara manual menggunakan buku agenda dan ditulis ulang menggunakan perangkat komputer untuk pencetakan dokumen, hal ini menyebabkan kurangnya efisiensi waktu dan tenaga. Oleh karena itu diperlukan sistem informasi yang dapat mengatasi permasalahan tersebut, penelitian ini mengusulkan perangkat lunak Sistem Informasi Akademik dan Mahasiswa (SIMA) yang dapat diakses kapan saja melalui jaringan internet dan penyimpanan pencatatan melalui database namun pada artikel ini membatasi mulai dari tahap analisis kebutuhan perangkat lunak hingga perancangan desain sistem.

\section{METODE PENELITIAN}

\section{A. Data Penelitian}

Pada penelitian pembuatan prototipe sistem informasi, data diperoleh dari hasil wawancara dengan Akmawa Universitas Pendidikan Indonesia Kampus Cibiru, analisis kebutuhan sistem, serta studi literatur untuk mendapatkan referensi terkait perangcan sistem yang dilakukan. 


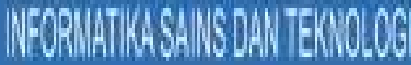

\section{B. Metode Pengembangan Sistem}

Pengembangan Sistem Informasi Akademik dan Mahasiswa (SIMA) menggunakan metode prototipe. Model prototipe merupakan pengembangan dari model wa terfall tersusun secara terurut pada gambar1.

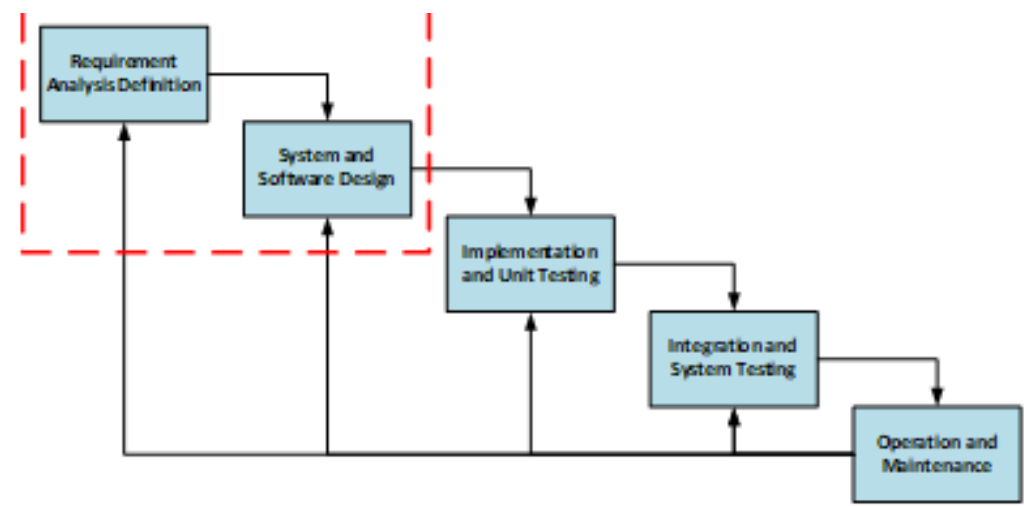

Gambar 1. Metode Waterfall (Abidin, 2017) dan (Sasmito, 2017)

Metode waterfall memiliki tahapan sebagai berikut (Abidin, 2017), (Jaya, 2017),(Josi, 2017)(Sasmito, 2017):

1. Requirements analysis definition

Tahap ini melakukan identifikasi masalah, studi literatur dan menentukan kebutuhan perangkat lunak.

2. System and software design

Menentukan kebutuhan sistem baik hardware maupun software dan penggambaran abstraksi beserta hubungan antar pengguna terhadap sistem informasi.

\section{Implementation and unit testing}

Tahap ini merupakan menterjemahkan tahap perancangan sistem informasi ke dalam bahasa pemrograman.

4. Integration and system testing

Modul program kedalam satu sistem untuk dilakukan pengujian.

5. Operation and maintenance 


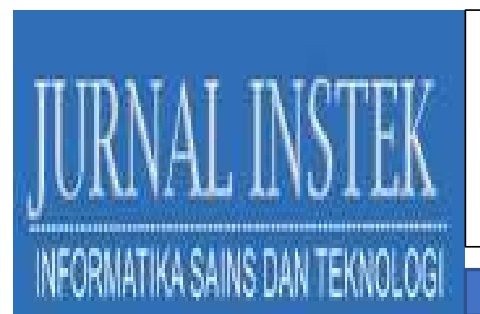

Volume 6 Nomor. 1, April 2021

P-ISSN : 2541-1179, E-ISSN : 2581-1711

Ojs :http://journal.uin-alauddin.ac.id/index.php/instek/index

Email : instek@uin-alauddin.ac.id

Tahapan terakhir pada metode ini dilakukan oleh pihak akademik dengan menerapkan sistem informasi akademik dan mahasiswa (SIMA) dan melakukan proses pemeliharaan sistem.

\section{Sistem yang diusulkan}

Rancangan sistem informasi akademik dan mahasiswa (SIMA) terdiri dari dua user atau pengguna yaitu akademik dan mahasiswa. Perancangan sistem dapat ditunujukan pada gambar 2 flowmap sistem informasi sebagai berikut:

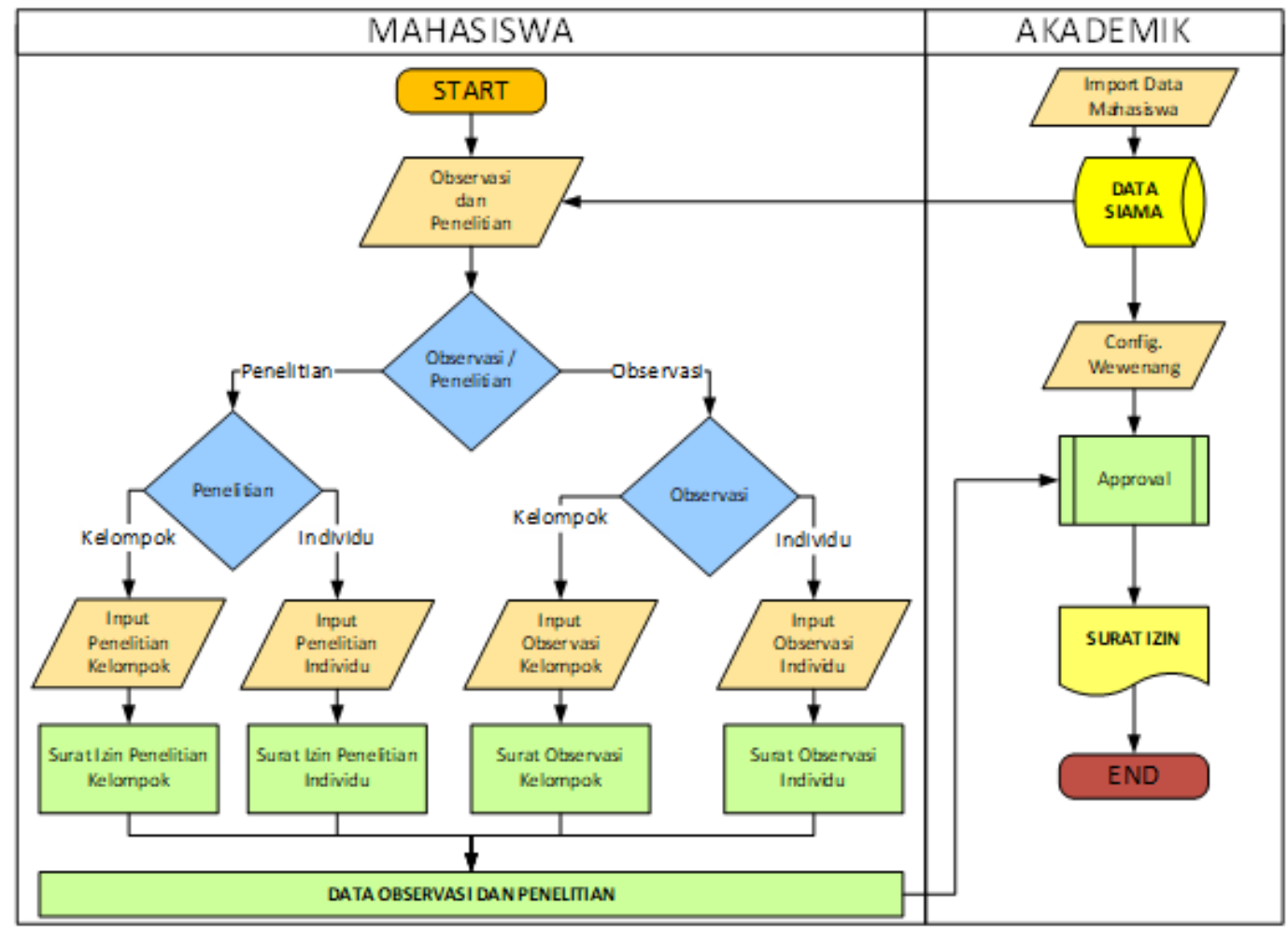

Gambar 2. Flowmap Sistem Informasi

Flowmap sistem informasi tersebut menjelaskan keterlibatan antar pengguna sistem sebegai berikut:

1. Akademik bertidak sebagai admin dalam sistem informasi menyedikan data mahasiswa yang aktif. Permohonan mahasiswa akan masuk pada menu yang ada pada akademik untuk dialakukan proses administrasi dokumen.

2. Mahasiswa dihadapkan pada halaman permohonan observasi atau penelitian. Mahasiswa mengisi data yang yang dibutuhkan oleh akademik. 
Volume 6 Nomor. 1, April 2021

P-ISSN : 2541-1179, E-ISSN : 2581-1711

Ojs :http://journal.uin-alauddin.ac.id/index.php/instek/index

Email : instek@uin-alauddin.ac.id

III. HASIL DAN PEMBAHASAN

\section{A. Penerapan Model Waterfall}

Pada artikel ini, pembatasan masalah dijelaskan pada bab I Pendahuluan maka metode pengembangan sistem informasi yang akan diterapkan menggunakan metode waterfall dibatasi sampai dengan tahap system and software design atau prototipe.

\section{B. Analisis Kebutuhan}

Sistem Informasi yang dirancang akan digunakan oleh dua user, berdasarkan sistem yang diusulkan maka akan didapatkan entitas akademik dan entitas mahasiswa.

\section{Analisis Spesifikasi Kebutuhan}

Spesifikasi kebutuhan menentukan kebutuhan sistem yang akan dirancang, proses yang harus ada dan bisa dilakukan oleh sistem yang akan dirancang terdiri dari:

1. Kebutuhan Fungsional

Kebutuaan fungsional search dan view, Mahasiswa dapat mencari dan melihat status permohonan observasi atau penelitian, sedangkan akademik dapat mencari dan melihat permohonan observasi ataupun penelitian. Kebutuhan fungsional input dan update, mengisi form permohonan observasi dan penelitian bagi mahasiswa dan memiliki fungsi update pada permohonan observasi dan penelitian bagi user akademik.

\section{Kebutuhan Non Fungsional}

Proses yang dapat dilakukan oleh sistem yaitu memiliki mudah digunakan atau bersifat user friendly, menyimpan data, diakses dimanapun dan kapan saja selama terhubung jaringan internet dan dapat diakses pada multiplatform dan multidevice.

\section{Desain Sistem}

Arsitektur sistem informasi menggambarkan relasi atau hubungan antar setiap user digambarkan dalam bentuk data flow diagram ditunjukan pada gambar 3. 

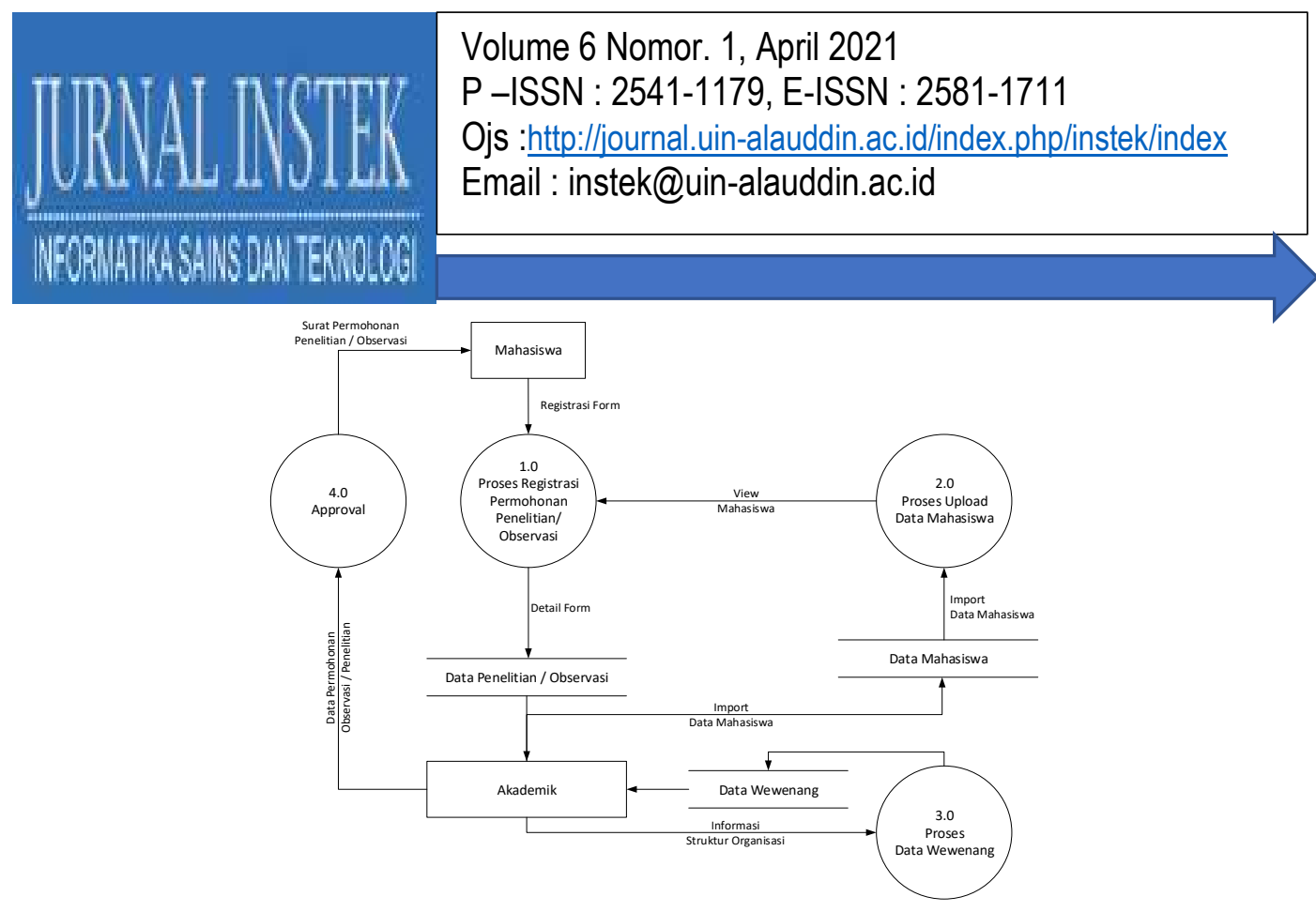

Gambar 3. Data Flow Diagram

Proses yang dilakukan pada sistem informasi akademik dan mahasiswa ditunjukan gambar 4. Proses 1 proses registrasi, pengisian form dengan menentukan jenisnya permohonan baik secara individu ataupun kelompok menggunakan Nomor Induk Mahasiswa dari proses 2. yaitu proses upload data mahasiswa. Data yang telah diisi oleh mahasiswa disimpan pada entitas akademik yang akan diproses pada proses 3 proses data wewenang, Proses terakhir yaitu proses 4. persetujuan permohonan data observasi atau penelitian yang akan ditandatangi oleh pejabat berwenang.

\section{E. Perancangan Basis Data}

Sistem dapat menyimpan data yang diinputkan oleh user menggunakan basis data dilakukan untuk memenuhi kebutuhan informasi ditunjukan pada Gambar 4 berupa data modul yang terdiri dari kumpulan entitas user yang saling beruhubungan.

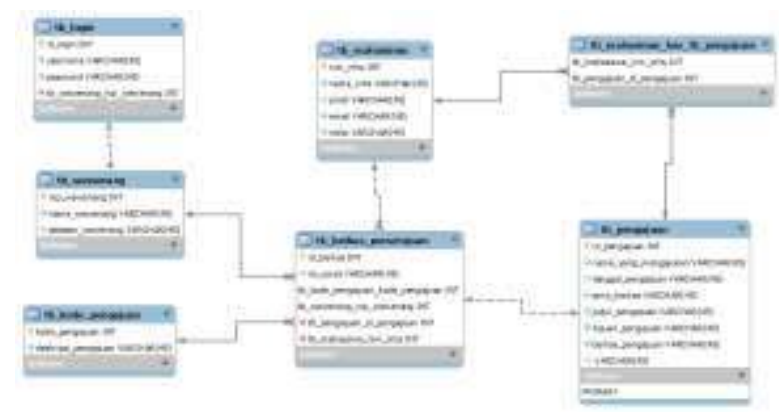

Gambar 4. Perancangan Basis Data 


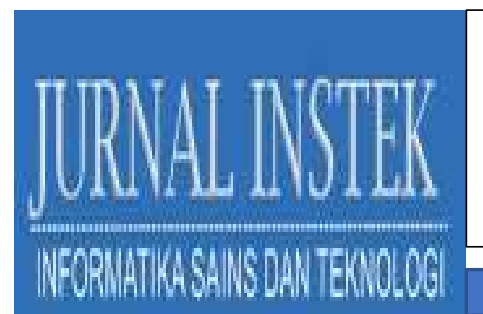

Volume 6 Nomor. 1, April 2021

P-ISSN : 2541-1179, E-ISSN : 2581-1711

Ojs :http://journal.uin-alauddin.ac.id/index.php/instek/index

Email : instek@uin-alauddin.ac.id

\section{F. Perancangan Antarmuka}

Untuk memenuhi kebutuhan fungsional dan non fungsional sistem informasi maka dirancang antarmuka user friendly. Perancangan antarmuka sistem terbagi menjadi dua bagian, yaitu backend yang dapat diakses oleh akademik dan frontend yang dapat diakases oleh mahasiswa ataupun umum.

Pada bagian backend prototipe sistem terdiri dari login user (Gambar 5), data mahasiswa (Gambar 6) data pejabat wewenang (Gambar 7) dan update permohonan observasi atau penelitian (Gambar 8).

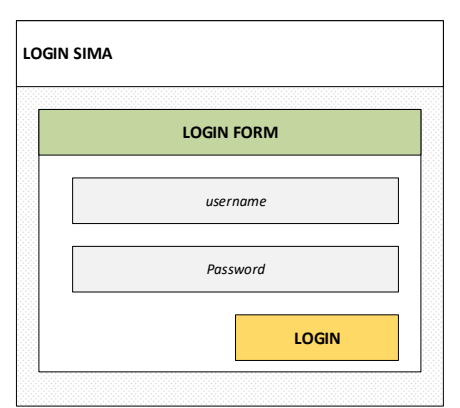

Gambar 5. Login sistem

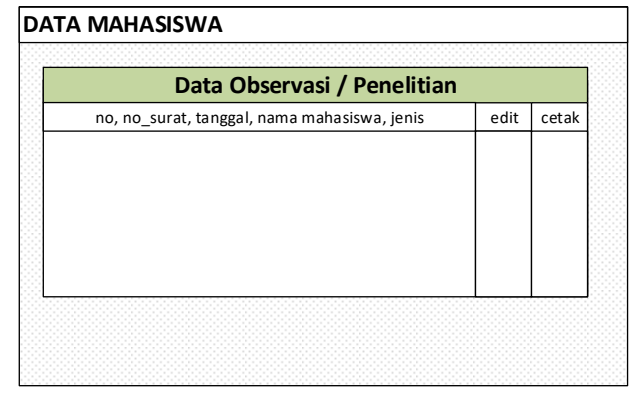

Gambar 6. Data List Mahasiswa Pemohon

Hanya akademik yang memliki username dan password untuk mengakses sistem informasi akademik dan mahasiswa.

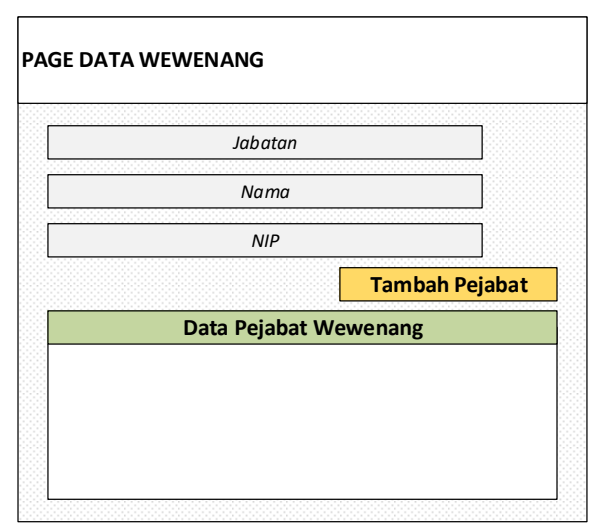

Gambar 7. Data List Pejabat Wewenang Sistem

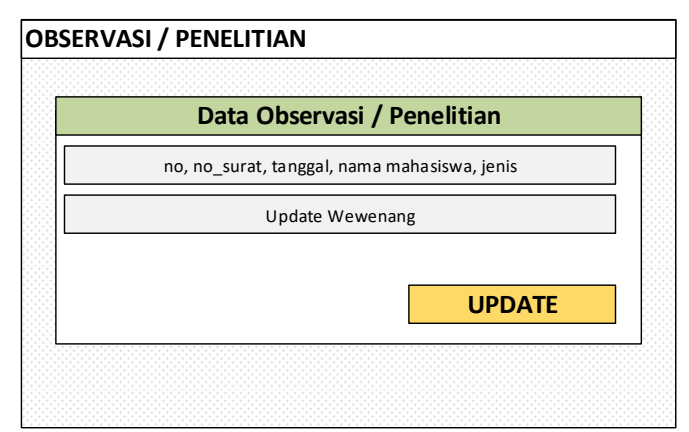

Gambar 8. Update permohonan pada sistem

Bagian frontend atau tampilan depan prototipe sistem yang dapat diakses oleh mahasiwa terdiri dari input permohonan secara perorangan (Gambar 9) dan input permohonan secara kelompok (Gambar 10). 


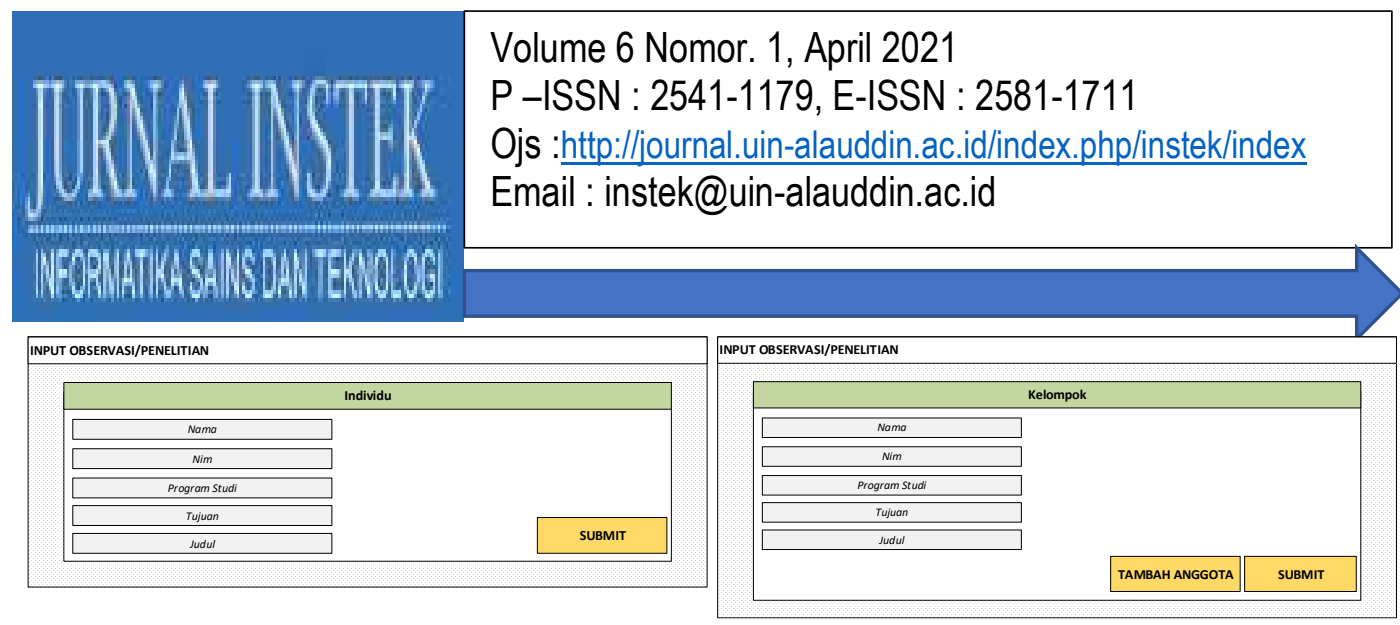

Gambar 9. Permohonan secara individu

Gambar 10. Permohonan secara kelompok

\section{G. Hasil Sistem Informasi}

Tampilan hasil Sistem Informasi Akademik dan Mahasiswa (SIMA) ialah ditunjukan pada gambar berikut:

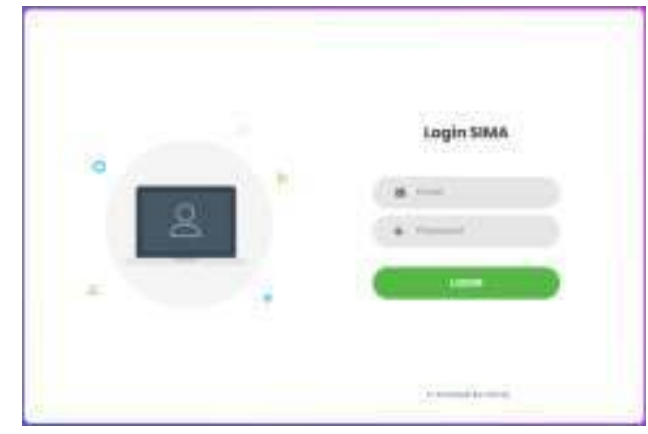

Gambar 11. Login SIMA

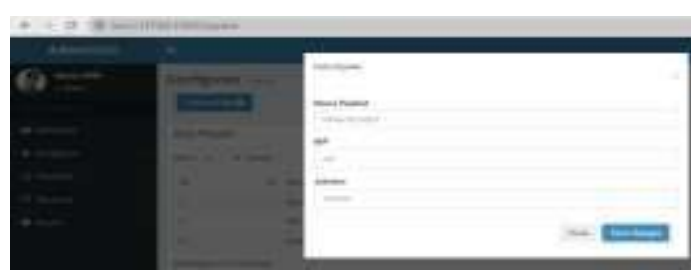

Gambar 13. Input data pada backend

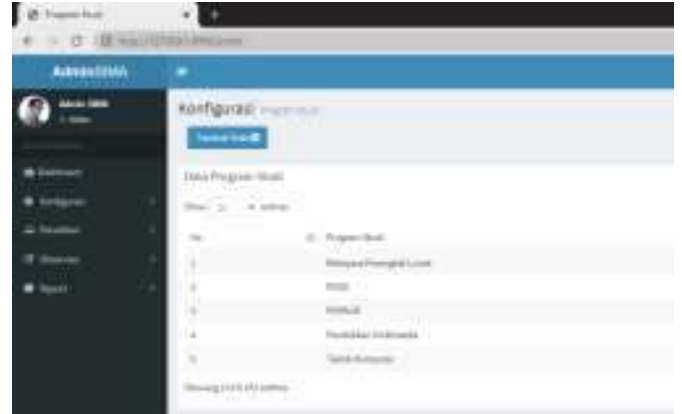

Gambar 12. Tampilan backend SIMA

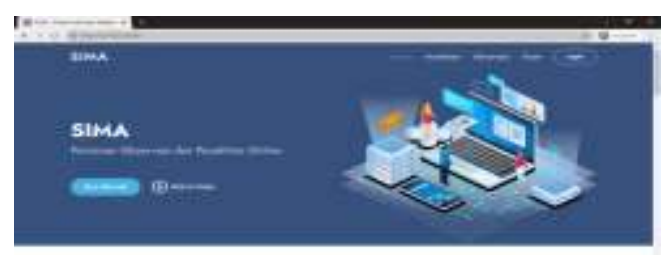

nour vo

Gambar 14. Tampilan Frontend SIMA

\section{H. Perbandingan Sistem}

Pengukuran dilakukan untuk membandingkan kinerja sistem baru terhadap sistem yang sedang berjalan ditujukan pada tabel 1. Perbandingan menunjukan sistem baru memiliki fungsional dan dapat meningkatkan pelayanan akademik. 


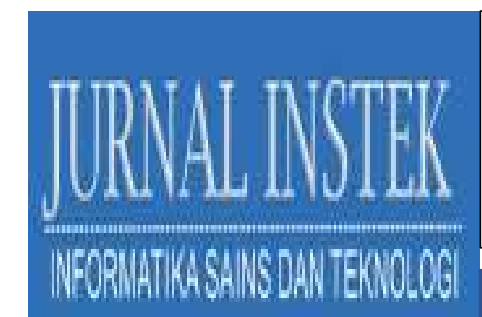

Volume 6 Nomor. 1, April 2021

P-ISSN : 2541-1179, E-ISSN : 2581-1711

Ojs :http://journal.uin-alauddin.ac.id/index.php/instek/index

Email : instek@uin-alauddin.ac.id

Tabel 1. Perbandingan sistem

\begin{tabular}{|l|l|l|}
\hline Permasalahan & \multicolumn{1}{|c|}{ Sistem lama } & \multicolumn{1}{c|}{ Sistem baru } \\
\hline Aplikasi & $\begin{array}{l}\text { Menggunakan perangakan lunak } \\
\text { Spreadsheet }\end{array}$ & $\begin{array}{l}\text { Aplikasi Sistem Informasi } \\
\text { Akademik dan Mahasiswa } \\
\text { (SIMA) }\end{array}$ \\
\hline Analisa Data & $\begin{array}{l}\text { Analisa data dilakukan } \\
\text { melakukan pencatatan pada buku } \\
\text { agenda sebelum pada } \\
\text { spreadsheet }\end{array}$ & $\begin{array}{l}\text { Penyimpanan data permohonan } \\
\text { observasi dan penelitian } \\
\text { disimpan menggunakan basis } \\
\text { data }\end{array}$ \\
\hline Proses & $\begin{array}{l}\text { Permohonan mendatangi bagian } \\
\text { akademik }\end{array}$ & $\begin{array}{l}\text { Permohonan dapat dilakukan } \\
\text { diamana saja dan kapan saja } \\
\text { melalui jaringan internet. }\end{array}$ \\
\hline Penyimpanan & $\begin{array}{l}\text { Penyimpanan disimpan melalui } \\
\text { buku agenda serta spreadsheet. }\end{array}$ & $\begin{array}{l}\text { Penyimpanan data permohonan } \\
\text { disimpan pada basis data. }\end{array}$ \\
\hline $\begin{array}{l}\text { Dokumen } \\
\text { Permohonan }\end{array}$ & $\begin{array}{l}\text { Memiliki lebih dari satu } \\
\text { dokumen fisik. }\end{array}$ & $\begin{array}{l}\text { Satu dokumen fisik dan } \\
\text { tersimpan pada basis data. }\end{array}$ \\
\hline
\end{tabular}

\section{IV.KESIMPULAN}

Prototipe Sistem informasi Sistem informasi akademik dan mahasiswa (SIMA) dirancang melalui pendekatan waterfall, salah satu tahapanya yaitu system and software design. Hasil penelitian ini disimpulkan bahwa desain sistem informasi meliputi flowmap, data flow diagram serta prototipe antarmuka dapat membantu pengembang dalam membangun perangkat lunak dengan tepat dan dapat memprediksi waktu yang dibutuhkan untuk menyelesaikan SIMA. Selain itu, untuk mengukur sistem yang diusulkan instrumen perbandingan antara lain aplikasi, Analisa data, proses permohonan, penyimpanan data serta dokumentasi permohonan mendapatkan hasil bahwa menggunakan sistem SIMA maka proses yang berjalan pada permohonan penelitian dan observasi efisien untuk diterapkan sebagai alat bantu tugas dan fungsi pokok akademik melalui penyimpanan data yang terstruktur menggunakan basis data, proses approval atau persetujuan lebih ringkas dan permohonan lebih efektif karena dapat yang dapat dilakukan tanpa memperhatikan lokasi dan waktu. 


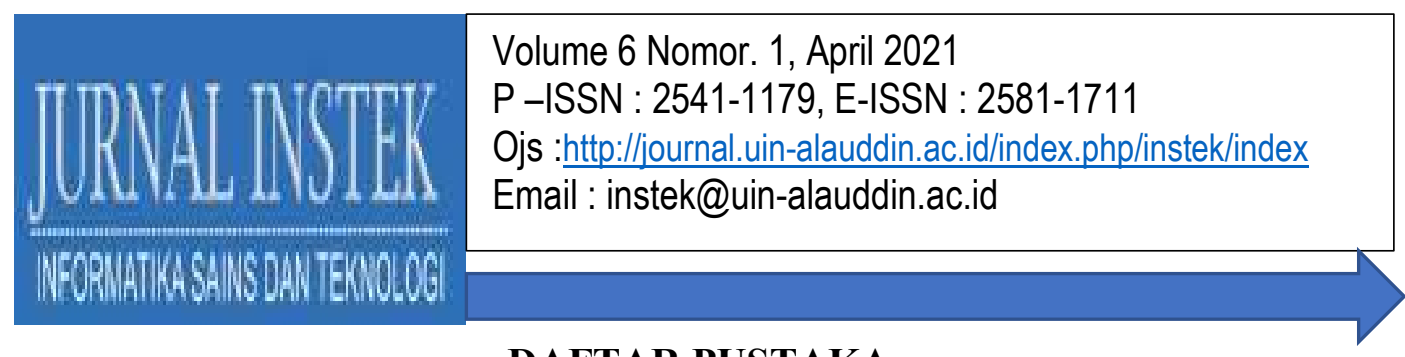

\section{DAFTAR PUSTAKA}

Abidin, T. and Wiyono, S., 2017. Rancang Bangun Sistem Informasi Kemahasiswaan (Studi Kasus: Program Studi D IV Teknik Informatika Politeknik Harapan Bersama Tegal). Jurnal Informatika: Jurnal Pengembangan IT, 2(1), pp.30-36.

Farell, G., Saputra, H.K. and Novid, I., 2018. Rancang Bangun Sistem Informasi Pengarsipan Surat Menyurat (Studi Kasus Fakultas Teknik UNP). JTIP: Jurnal Teknologi Informasi dan Pendidikan, 11(2), pp.55-62.

Hasanudin, M., Kristiadi, D.P., Roihan, A. and Haris, H., 2020. Rancang Bangun Sistem Informasi Jasa Proyek (SiJasPro) berbasis Mobile. IT Journal Research and Development, 4(2).

Homaidi, A., 2016. Sistem Informasi Akademik AMIK Ibrahimy Berbasis Web. Jurnal Ilmiah Informatika, 1(1), pp.17-23.

Jaya, T.S. and Sahlinal, D., 2017. Perancangan Kantor Digital Berbasis Framework dengan Metode Waterfall pada Politeknik Negeri Lampung. Jurnal Informatika: Jurnal Pengembangan IT, 2(2), pp.14-17.

Josi, A., 2017. Implementasi Algoritma Genetika Pada Aplikasi Penjadwalan Perkuliahan Berbasis Web Dengan Mengadopsi Model Waterfall (Studi Kasus: STMIK Prabumulih). Jurnal Informatika: Jurnal Pengembangan $I T, 2(2)$, pp.77-83.

Prihandoyo, M.T., 2018. Unified Modeling Language (UML) Model Untuk Pengembangan Sistem Informasi Akademik Berbasis Web. Jurnal Informatika: Jurnal Pengembangan IT, 3(1), pp.126-129.

Pusparini, E.S., Najoan, M.E. and Najoan, X.B., 2017. Sistem Informasi Akademik Berbasis Mobile Web menggunakan Pendekatan Metodologi RAD (Studi Kasus: Universitas Sam ratulangi). Jurnal Teknik Elektro dan Komputer, 6(4), pp.182-193.

Rerung, R.R. and Ramadhan, Y.R., 2018. Rancang Bangun Sistem Informasi Akademik dalam Penerapan Smart Campus untuk Meningkatkan Pelayanan Akademik. vol, 3, pp.191-210. 